\title{
Manajemen Aset Wakaf Berbasis Kearifan Lokal Dengan Pendekatan Sosio-Ekonomi di Lembaga Wakaf Sabilillah Malang
}

\author{
Basar Dikuraisyin \\ Universitas Islam Nengeri Sunan Ampel Surabaya, Indonesia \\ Email: basardikuraisyin@uinsby.ac.id
}

\begin{abstract}
This study aims to disclose the model of waqf asset management carried out by the waqf foundation of Sabilillah Malang. This disclosure is essential, given the high number of waqf assets in Indonesia that are not managed. The significance of this study lies in the strategies and approaches utilized, including the strategy of bringing local wisdom as a management base on the social and economic development of the local community. Specifically, this study is included in the research area of social institutions that are descriptive, along with a qualitative analysis approach. The data collection technique used two methods, including interviews and documentation. The sample of informants was chosen randomly (purposive sampling). In this case, the position of the researcher was a participatory observer, where the data instruments were in the researcher's assumptions. After the research was conducted, some crucial findings, include 1) in performing the process of asset management, the first step to do is identifying the assets in the form of a human, natural, and social assets. 2) developing assets by maximizing local potentials. A number of identified local potentials are developed through the provision of facilities like cooperatives, minimarkets, food courts where all elements of the development are under the direct coordination of the economic and empowerment centers. 3) developing waqf assets by maximizing the sources of local potentials by engaging small business enterprises as business partners, setting up businesses by providing capital, and establishing businesses by credit. All this cooperation is packed up using mudharabah, murabahah and musyarakah contracts.
\end{abstract}

Keywords : Asset management, waqf, local wisdom

\section{Latar Belakang}

Aset wakaf di Indonesia memiliki potensi yang sangat besar untuk dikembangkan. Tiga tahun terakhir, Kementerian Agama merilis laporannya mengenai aset wakaf. Tanah wakaf mencapai 3 miliar persegi dengan sebaran 420 hektar di seluruh lokasi di Indonesia, aset tersebut bernilai 2000 triliun (kemenkeu.go.id, 2020). Meskipun Indonesia tergolong sebagai negara dengan potensi wakaf yang besar, namun sampai saat ini negara kita belum memiliki cetak biru (blueprint) pengembangan aset wakaf. Potensi aset wakaf yang sedemikian besar ini diharapkan menjadi solusi kemiskinan dan pengangguran di masyarakat.

Sumber daya manusia untuk mengelola potensi tersebut masih lemah sehingga menjadikan aset wakaf tidak dapat dimanfaatkan secara optimal. Terhitung hanya $23 \%$ aset wakaf yang dimanfaatkan, itupun $72 \%$ untuk pembangunan masjid dan 
mushalla, $14 \%$ untuk sekolah dan pesantren, sisanya $8.6 \%$ untuk kegiatan sosial. Jumlah ini mengilustrasikan bahwa betapa banyak tanah dan aset wakaf lainnya yang diam bertahun-tahun tidak berdaya guna. Betapa banyak lahan tanah wakaf dibiarkan saja tanpa dikelola. Lalu bagaimana mungkin aset wakaf dapat menutup jurang kemiskinan.

Wakil presiden RI, Ma'ruf Amin menyatakan bahwa rendahnya kompetensi pengelola wakaf (nadzir, read.) menjadi penyebab utama yang selama ini digodok oleh pemerintah dengan beragam pelatihan serius. Namun, program ini belum juga menunjukkan hasil maksimal (www.suara.com, 2020). Padahal sebagian besar, aset wakaf yang berupa tanah, berada pada lokasi strategis untuk dikembangkan. Senada dengan Ma'ruf Amin, Nilna Fauza (2019) membenarkan dengan riset terbarunya bahwa nadzir merupakan kelemahan utama, sebab kinerja pengelolaan nadzir hingga kini sebatas pada cara-cara tradisional, seperti membangun tempat ibadah, kuburan, dipasang patok saja (Nilna, 2015).

Persoalan teknik lainnya, mari lihat pada penelitian yang dilakukan oleh Nugroho (2016), di beberapa daerah Indonesia, banyak terjadi penguapan harta wakaf atau tidak diadministrasikan secara resmi. Sehingga, kerap dicaplok dan disertifikasi oleh pihak yang ahli waris dan oknom lain. Banyak aset wakaf yang dikuasai individu, mengakibatkan masalah pelik yang menuntut adanya perbaikan administrasi melalui sistem informasi (Fahmi et al., 2016). Tentu, bagian masalah yang ketiga ini lebih runyam mengingat bias hukum yang ditimbulkan. Jika tak kunjung dicarikan solusi, bukan tidak mungkin aset wakaf keberadaannya terancam diambil alih.

Upaya pemanfaatan aset wakaf ini dapat dimulai dari pemberdayaan masyarakat ekonomi. Sebagai contoh, pemanfaatan aset wakaf dengan mendirikan koperasi. Lembaga wakaf dapat mendirikan bait al-maal wa at-tanwil berbasis murabahah, pemberian modal usaha menggunakan konsep mudharabah, pengembangan lahan melalui bagi hasil dengan petani, ini semua dirangkul oleh koperasi wakaf (Munir, 2015) Optimalisasi ini bukan hanya mengelola aset wakaf menjadi produktif, namun juga menyisir wilayah-wilayah ekonomi masyarakat yang lebih nyata.

Strategi pengelolaan aset wakaf juga dilakukan di Masjid Agung Semarang. Masjid yang menjadi pusat ibadah umat Islam, dimanfaatkan dengan cara mendirikan SPBU mini. Lembaga wakaf menyediakan modal dan fasilitas, sementara pengelolanya adalah masyarakat yang membutuhkan sokongan dana. SPBU Masjid Agung Semarang ini mampu mendirikan ATM, minimarket dan klinik yang diambil dari aset wakaf. Lembaga wakaf bukan hanya menjadi tempat ibadah, namun juga disambi bisnis yang dapat menghasilkan bagi kaum miskin (Usman, 2016).

Model pengelolaan aset wakaf yang komprehensif, meliputi manajemen pendidikan, kesehatan, koperasi, sosial sampai pada wilayah pemberdayaan ekonomi bawah, terdapat pada lembaga wakaf di Malang. Sejauh ini Kota dan Kabupaten Malang memiliki reputasi yang baik dan menuai banyak penghargaan baik dari pusat maupun propinsi berkat pengelolaan wakaf profuktif yang dinilai sukses. Masjid Sabilillah Malang, menjadi masjid di Indonesia yang dijadikan percontohan tingkat nasional dalam mengelola aset wakaf. Berdiri tahun 1999, lembaga wakaf Sabilillah Malang berhasil menyulap aset wakaf menjadi sekolah inklusi dan formal, kesehatan beserta ambulans, koperasi dengan cabang-cabannya seperti unit pertokoan, BMT, 
mall Pujasera. Lembaga wakaf ini mampu melakukan pengembangan sektor ekonomi yang komersial, memodali UMKM sampai hilir dan bahkan bermetamorfosis mendirikan perusahaan wakaf (www.nu.or.id, 2020). Lembaga wakaf di Malang ini, memiliki reputasi manajemen aset wakaf yang efektif dan efisien.

\section{Teori dan Metode}

\subsection{Manajemen Aset}

Manajemen aset bertujuan untuk memberikan manfaat dengan optimal aset yang dimiliki agar menjadi efektif dan efesien. Seperti yang diungkapkan Britton dan Connellan sebagaimana dikutip oleh Suhendi, "Asset management is difine good asset management in term of measuring the value of properties (asset) in monetary term and employing the minimum amunt of ezpenditure on its management" (Suhendi, 2018) Pengertian ini kemudian dilengkapi oleh Sugiana, mengatakan yang dimaksud manajemen aset adalah ilmu yang mempelajari tentang kegiatan pengelolaan aset, mencakup perencanaan kebutuhan aset, investasi, pendapatan, legal audit dan pengoperasian secara efektif dan efesien (Asytuti, 2017).

Sutaryo (2015) menjabarkan yang dimaksud manajemen aset merupakan perpaduan antara ilmu manajemen, ekonomi, keuangan dan teknik yang terfokus pada prinsip pengeluaran dan pendapat efektif. Dari pengertian ini, dapat ditarik benang merah yang dimaksud dengan manajemen aset yaitu rangkaian aktifitas terukur sebagai upaya mengembangkan aset mulai dari aktifitas perencanaan sampai pada evaluasi untuk mendapatkan hasil yang efektif dan efisien.

Point utama dari manajemen aset di atas adalah efisiensi dan efektif. banyak pola manajemen yang dilakukan pada bidang lain, namun tidak sampai pada tingkatan efisiensi. Siregar (2004) menjelaskan varian efisiensi dalam manajemen aset, yaitu 1) efisiensi yang bersifat kepemilikan dan pemanfaatan. Pengelolaan aset yang dipoles dengan tugas pokok dan fungsi berimplkasi pada hasil yang optimal. 2) nilai ekonomis terjaga, aset yang dikelola dengan benar dan tepat akan menghasilkan aset ekonomi tetap dan meningkatkan pendapatan. 3) adanya obyektifitas dalam pengawasan, pengendalian dan pengalihan kekuasaan (Via Olva Novita, 2020).

Dari perbedaan definisi di atas, dapat disimpulkan yang dimaksud manajemen aset adalah aktifitas atau kegiatan yang dimulai dengan perencanaan, pengorganisasian, pelaksanaaan dan evaluasi dengan mengacu pada standar efisien dan efektif agar aset yang dimiliki dapat memberikan hasil prduktif. Simpulan definisi ini sekaligus berimplikasi bahwa setiap aset dapat dikatakan terkelola dengan benar, apabila telah menghasilkan dan berkembang.

Siregar yang dikutip oleh (Novita, 2020), memberikan standar capai manajemen aset ke dalam tiga kategori; pertama, efisiensi pemilikan dan pemanfaatan. Dalam hal ini, aset harus jelas pemilik dan statusnya. Aset yang menjadi hak milik umum (bukan milik individu) dikelola secara teamwork atau kerja tim, sedangkan aset yang menjadi milik individu dikelola secara kekeluargaan. Intinya, status aset tersebut harus terlebih dahulu diperjelas untuk mendapatkan hasil yang maksimal. Kedua, memiliki nilai ekonomis yang stabil. Tujuan manajemen aset tersebut, selain untuk dikembangkan, juga menjaga agar terus menghasilkan. Ketiga, 
obyektifitas pengawasan dan pengendalian. Dalam melakukan manajemen, aset tersebut harus bisa diawasi.

Prinsip-prinsip aset dapat terealisasi, apabila siklus aset dalam teori manajemen dapat terlaksana dengan benar. Siklus aset merupakan komponen penting yang harus dilewati dalam melakukan manajemen aset. Alhifni et al., (2017). Alhifni mengatakan bahwa, fase siklus majemen aset dimulai dari tahap perencanaan, inventarisir, penilaian, pengoperasian aset dan rejuvinasi.

\subsection{Manajemen Wakaf}

Pengelola aset wakaf (selanjutnya disebut nadzir) memerlukan pola manajemen. Manajemen ini bisa terdiri dari penghimpunan aset wakaf, sertifikasi, pengembangan, pengelolaan, menjaga hubungan dengan wakif, dan memprodktifkan aset wakaf. Tentu, semua lembaga wakaf menginginkan hasil kerja pengelolaannya efektif dan efisien. Dengan demikian, manajemen aset wakaf merupkan upaya serius untuk melakukan proses perencanaan, pengorganisasian, kepemimpinan an pengenalian aset wakat dengan memberdayakan sumber daya organisasi untuk mencapai tujuan (Amania, 2018).

Manajemen setidaknya untuk mencapai tujuan, menyeimbangkan kelemahankelemahan dan untuk mencapai efisiensi dan efektifitas. Terry (2009) sebagaimana dikutip oleh Alhifni, membagi unsur manajemen menjadi empat hal, yakni planning (perencanaan), organizing (pengorganisasian), actuating (pelaksanaan) dan controlling (pengawasan) (Alhifni et al., 2017). Pada tataran manajemen wakaf, sebenarnya unsur tersebut sama sekali tidak berubah. Hanya saja, yang menjadi obyek manajemen adalah wakaf.

Pertama, planning (perencanaan) wakaf. Secara garis besar, planning berkenaan dengan kegiatan yang harus dilaksanakan oleh anggota untuk mencapai tujuan. Planning mencakup cara atau strategi pengambilan keputusan diantaranya adalah sasaran (goal) dan rencana (plan) (Alhifni et al., 2017). Karena planning merupakan langkah awal yang signifikan dan menentukan, maka dibutuhkan kemampun sumber daya yang cakap dan profesional untuk menyusun planning. Diperlukan pola pemikiran visualisasi yang dapat menerka ke depan.

Dalam hal wakaf, posisi planning berada beberapa hal, yakni; 1), apa tujuan dilakukannya manajemen aset wakaf tersebut, apakah untuk kemaslahatan umum seperti pemakaman, tempat ibadah, sekolah, rumah sakit atau yang lain. 2) menentukan program pengembangan aset wakaf, 3) melihat resiko kerugian dan keuntungan dari aspek efektifitas aset wakaf, 4) melakukan identifikasi berupa potensi aset wakaf dan terakhir, 5) menyiapkan alternatif apabila terdapat kegagalan dalam pelaksanaan program manajemen aset wakaf (Rozalinda, 2015).

Kedua, organizing (pengorganisasian) lembaga wakaf. Organizing, yaitu proses pemeta-metaan kegiatan sekaligus penunjukan anggota yang ditugaskan untuk melaksanakan kegiatan tersebut untuk mencapai tujuan. Terry dan Rue, mengatkaan bahwa organizing bertujuan untuk mengatur sumber daya yang diperlukan seperti men (manusia), method (cara atau sistem), mechine (mesin atau fasilitas), material (bahan yang diperlukan) dan market (tempat untuk produksi) (Asy`ari, 2017).

Organizing memiliki beberapa komponen yaitu 1) work, yaitu pelaksanaan manajemen aset yang disusun berdasarkan sasaran yang telah ditetapkan; 2) 
employess, pengurus lembaga wakaf yang ditugaskan untuk melaksanakan program atau kegiatan; 3) relationship, harmonisasi hubungan antar anggota atau pengurus, antar wakif dan muwakkif, antara pimpinan dengan anggota; 4) environment, yaitu sarana fisik di lingkungan proses manajemen, di mana para nadzir melakukan aktifitas pelaksanaan program (Rozalinda, 2015).

Ketiga, actuating (pelaksanaan) program atau kegiatan aset wakaf. Dalam ilmu manajemen, actuating diartikan dengan pelaksanaan program yang telah direncanakan melalui usaha atau gerakan para angota kelompok dengan sangat bersungguh-sungguh, mengupayakan sesuai perencanaan bersama (Asy`ari, 2017). Para anggota atau pengurus yang terpisah sesuai struktur dan bidangnya, digerakan bekerja sesuai program dan tugasnya masing-masing dengan tetap mengacu pada sasaran dan tujuan.

Jika dihubungkan dengan manajemen aset wakaf, maka unsur actuating ini telah sampai pada tahap pelaksanaan segala program manajemen aset dari masingmasing tugas oleh nadzir sesuai bidangnya masing-masing. Dalam melaksanakan program selama jangka waktu periode tertentu, umumnya, harus bersandar pada tujuan manajamen aset wakafnya. Karena bila menyimpang, program tersebut dapat dikatakan gagal.

Keempat, controlling (pengawasan). Adalah control atau penilaian terhadap kinerja capaian yang menjamin bahwa program atau kegiatan benar-benar sesuai dengan rencana yang telah ditetapkan (Asy`ari, 2017). Tahap ini sangat penting dilakukan, mengingat terkadang ada beberapa program yang tidak terlaksana. Ada juga yang terlaksana, hanya saja luput dari tujuan yang diingingkan. Fungsi controlling inilah, satu sisi sebagai evaluasi dan disisi lain berfungsi sebagai pembaruan. Maksud pembaruan adalah apabila terdapat program yang tidak sesuai, maka diperbaharui dengan program lainnya.

Begitu juga pada aspek controlling aset wakaf, beberapa langkah kerap dilakukan untuk melakukan tahapan controlling. Diantaranya adalah 1) menentukan standarisasi minimal capaian dari setiap program manajemen aset wakaf; 2) menentukan pengukuran pelaksanan program manajemen aset wakaf; 3) kemudian melakukan pembandingan dengan program lainnya; 4) apabila terdapa kesimpangsiuran diadakan pengambil alihan koreksi untuk memuluskan manajemen aset wakaf.

\subsection{Kearifan Lokal}

Kearifan lokal berarti pandangan hidup (word view) yang dimiliki oleh satuan masyarakat lokal sebagai wujud untuk memenuhi unsur budaya dan kebiasaan mereka. Diniah sepakat dengan pengertian ini, menurutnya, karifan lokal hasil kecerdasan manusia yang diperoleh melalui pengalaman hidup mereka dalam bermualamah (social socity) (Daniah, 2016). Dalam perspektif kekinian, kearifan lokal dapat dipandang sebagai sistem sosial yang menghasilkan autopoesis (pengorganisasian diri) dalam suatu kerangka kebudayaan masyarakat (Pesurnay, 2018).

Koentjaraningrat, Sparadley, Taylor dan Suparlan sebagai ahli antropologi menyebut kearifan lokal sebagai variabel yang memiliki kategorisasi, dimana kebudayaan manusia memiliki aspek kearifan lokal yang terdiri dari idea, aktivitas sosial dan etifak (Daniah, 2016). Dengan asumsi antropolog ini, memastikan kalau 
kearifan lokal bagian (bukan sinonimnya) dari kebuayaan, hanya saja, kearifan lokal ditekankan pada aspek idealisme, kegiatan masyarakat dan bukti-bukti kebuayaan manusia.

Peran kearifan lokal sangat penting untuk mempertahankan potensi daerah dan kebuayaan lokal. Seperti yang diungkapkan oleh Emi Ramdani (2018), bahwa kearifan lokal merupakan bagian dari budaya sebagai ciri khas suatu masyarakat. Kearifan lokal mengandung nilai yang dapat membendung arus perubahan zaman, menjadi karakter daerah sekaligus karakter bangsa (Ramdani, 2018). Sebagaiana dikuatkan oleh penapat Yunus dalam artikel Selasih, bahwa kearifan lokal merupakan jati diri bangsa dari aspek pengembangan karakter budaya (cultural character) berfungsi untuk membangn karakter bangsa (national and character building). (Selasih \& Sudarsana, 2018).

Beberapa pemaknaan menyinggung bahwa kearifan lokal memiliki beberapa unsur, diantaranya adalah budaya, peninggalan berupa bangunan, lingkungan alam seperti air terjun, pantai dan lain sebagainya, adat istiadat, seni, sumber daya, dan lain-lain yang mengilustrasikan potensi daerah dan kebudayaan setempat. Maka dengan ini, jelas bahwa kearifan lokal sangat terkait dengan kedaerahan, bukan pada

kondisi nasional. Aktifitas dikatakan kearifan lokal, jika melekat dan dilestarikan oleh daerah. Meskipun, antar daerah terkadang memiliki kearifan lokal yang berbeda. Kearifan lokal bersifat generatif. Keberadannya diwariskan dari generasi ke generasi setelahnya. Dikembangkan dengan melihat aspek relevansi dan kebutuhan masyarakat. Upaya untuk mengembangkan potensi daerah -semisal pengembangan ekonomi- melalui kearifan lokal pernah diteliti oleh Siti Aisyah dengan mengusung

konsep integrasi masyarakat syariah dengan konsep kearifan lokal. Memanfaatkan unsur budaya, adat istiadat, norma masyarakat untuk keberlangsungkan UMKM (Daniah, 2016). Ini tentu terobosan baik, dimana kearifan lokal mampu memberikan solusi.

Pengembangan potensi daerah melalui pengembangan ekonomi berbasis kearifan lokal juga pernah diformulasikan oleh Azizah dan Yeny (2018), dalam mengembangkan model ekonomi pesantren malalui maksimalisasi kearifan lokal. Konsep pengembangan ekonomi yang ditawarkan adalah kesinambungan antara stakeholder lembaga keuangan syariah dengan nilai kultural yang dinamakan dengan sosio-economy political. Keberlangsungan kerjasama ini mampu mengembangkan ekonomi pesantren di Ponpes Sidogiri (Azizah, 2018).

Dengan data ini, jelas bahwa kearifan lokal menjadi pendekatan yang dapat dijadikan solusi bagi pengembangan sumber daya, termasuk pengembangan aset wakaf. Dengan memanfaatkan potensi kearifan lokal, aset dapat dikelola sesuai potensi masyarakat dan daerahnya. Hal ini melahirkan relevansi antara obyek dengan subyek. Obyek adalah masyarakat sebagai sasaran manajemen, sedangkan subyek merupakan sumber daya yang melakukan manajemen dengan menggunakan pendekatan kearifan lokal.

\subsection{Metode Penenelitian}

Penelitian ini bermaksud mendeskripsikan model pengembangan aset wafaf di Malang seperti di Sabilillah Malang melalui manajemen aset wakat berbasis kearifan lokal. Dengan cara ini, maka pengambilan data di lapangan akan bersifat deskriptif mengungkap seluruh elemen yang berhubungan dengan asumsi penelitian. Maka 
dalam hal ini, segala data yang diperoleh merupakan kemampuan peneliti di lapangan sekaligus menempatkan peneliti sebagai alat pengumpul data (Sugiyono, 2016).

Penelitian ini menggunakan model penelitian kualitatif dengan asumsi research and development, maksud dari model penelitian ini yakni penelitian dilakukan secara bertahap dan berkembang dengan corak kualitatif (Sugiyono, 2018). Kualitatif itu sendiri diartikan sebagai metode penelitian yang digunakan pada kondisi obyek alamiah, model metode ini juga disebut dengan metode naturalistik, ekspremental dan etnographi. Sementara research and development, merupakan asumsi dasar penelitian yang dimulai dengan pendahuluan, pengembangan dan pelaksanaan (Sugiyono, 2016).

Pengambilan sampel penelitian ini termasuk pada teknik pengambilan sampel non probability, sebuah teknik pengambilan sampel yang tidak memberi peluang/kesempatan sama bagi setiap unsur atau anggota populasi untuk dipilih menjadi sampel (Moleong, 2017). Teknik pengumpulan data yang dilakukan menggunakan adalah observasi, wawancara dan dokumentasi. Menurut Nasution (1988) observasi adalah dasar semua ilmu pengetahuan. Begitu juga dengan Marshall (1995) sebagaimana dikutip oleh Sugiono, mengatakan bahwa through observation, the researcher learn about behavior and the meaning attached to those behavior (Moleong, 2019).

Data yang telah didapatkan, kemudian dianalisis menggunakan model analisis data Miles and Huberman yaitu reduction, display dan conclusion (Sugiyono, 2016). Pada tahap akhir, seluruh data dianalisis keabsahannya dengan menggunakan tekhnik triangulasi sumber melalui pengecekan ulang melalui tahap akhir observasi (triangulasi sumber tunggal) dan melalui dokumen-dokumen teoritik yang memiliki keterkaitan, baik dokumen yang didapat dari media online maupun berupa fisical.

\section{Hasil dan Pembahasan}

\subsection{Sekilas Laziz Sabilillah Malang}

Secara historis, sebagaimana dicatat pada dokumentasi, Lembaga Wakaf Sabilillah Malang merupakan bangunan masjid pada umumnya. Diayomi Kementerian Agama sejak tahun 1980 berbentuk yayasan diberi nama Yayasan Sabilillah. Pada mulanya, Masjid Sabiilillah hanya tempat ibadah biasa, bukan lembaga wakaf atau lembaga filantropi. Mendapat respon positif dari para donatur, KH. Tholchah Hasan bersama beberapa tim ingin memperluas jangkauan Masjid Sabilillah menjadi lembaga sosial yang bergerak di bidang Zakat, Infak, Sadaqah dan Wakaf (Zizwaf) tanpa mengurangi fungsi utamanya sebagai tempat ibadah. Selain antusiasme masyarakat yang mendukung, faktor geografis dimana Masjid Sabilillah terletak di pusat Kota Malang.

Terlepas dari manajemen aset wakaf yang produktif, Laziz Sabilillah Malang memiliki lokasi yang strategis berada di titik pangkal pengembangan sosial, politik, ekonomi dan pendidikan. Terbangun di tengah kota, Masjid Sabilillah Malang tercatat sebagai salah satu masjid perjuangan para pahlawan kemerdekaan, sehingga divisikan menjadi pusat dakwah, peradaban dan pusat pemberdayaan masyarakat. Aset dapat dikembangkan setidaknya harus memiliki tiga hal; lokasi strategis, potensial dan sumber daya yang mumpuni.(Sirajuddin et al., 2018). Sesuai dengan 
fungsinya, Laziz ini dinaungi oleh Yayasan Sabilillah Malang yang bervisi memakmurkan masjid dan mensejahterahkan masyarakat, terutama pada kaum dhuafa.

Dengan visi tersebut, fungsi masjid bukan sekadar tempat beribadah seperti pada umumnya di Indoensia, melainkan berkembang pada aspek sosial, pendidikan dan ekonomi (Margolang, 2018). Pada aspek sosial, Laziz melakukan pembinaan, pendampingan serta santunan dalam bentuk pelayanan kepada masyarakat sebagai misi meningkatkan kesejahteraan dan meningkatkan sumberdaya, hal ini dilakukan dengan variasi pengembangan dana zakat, wakaf dan infaq shadaqah. Aspek pendidikan, yayasan Sabilillah Malang makin mentereng lagi, jenjang pendidikan mulai kelas Taman Kanak-kanak, Madrasah, Tsanawiyah, sampai Aliyah dan Diniyah beberapa kali mendapat penghargaan. Pada aspek ekonomi, Laziz Sabilillah Malang memiliki banyak bisnis usaha seperti Medical Center, Pujasera, Mart dan sebgainya. Aspek-aspek ini merupakan sumbe daya yang dibangun untuk kepentingan manajemen aset wakaf, diantara aset-aset sumber daya tersebut adalah:

Pertama, koperasi Sabilillah. Koperasi ini dibangun menggunakan harta kekayaan wakaf murni. Aset wakaf berupa lahan kosong dibangun memakai harta wakaf yang terkumpul, kemudian mendirikan koperasi tepat di belakang Masjid Sabilillah. pembangunan koperasi ini, sejak mula memang ditujukan untuk meraup sebanyak mungkin keuntungan, kemudian keuntungan tersebut diberikan kepada keluarga miskin melalui model bantuan modal dan sistem kerjabagi musyarakah, yaitu jika mampu memperoleh keuntungan, maka $40 \%$ masuk sebagai wakaf tunai dan $60 \%$ sisanya untuk pengelola (keluarga miskin). Namun bila usaha tersebut gagal, maka pengelola tidak usah mengembalikan modal usaha. Model pengelolaan tersebut, merupakan akad musyarakah qard al-hasan yang menjadi jurus jitu ekonomi syariah (Rahmawati, 2016).

Kedua, Kantin Pujasera. Didirikan tahun 2012 dibangun menggunakan dana wakaf sesuai dokumentasi Laziz Sabilillah, kantin tersebut terletak sebelah utara Masjid Sabilillah. Kantin Pujasera terbangun atas inisiatif para anggota koperasi yang melihat peluang besar untuk mengembangkan aset wakaf, sebab bagian utara selain lahan aset wakaf Sabilillah juga strategis untuk semua jalur lalulalang orangorang. Kantin ini berbentuk mini market yang memadukan konsep modern dan jagong maton.

Ketiga, Sabilillah Medical Service (SMS). Aset wakaf yang satu ini diresmikan pada tahun 2009 dan mendapat izin operasional pada tahun 2010 sebagai produk pengembangan aset produktif dengan label syariah. Terdiri dari banyak produk pilihan seperti klinik kesehatan, mitra kerjasama bisnis dengan beberapa perusahaan dan perguruan tinggi. Tujuan didirikannya SMS ini adalah eksternalisasi aset wakaf dengan mengusung konsep kemanfaatan sosial dan kemaslahatan umat. Sabilillah Malang menjadi bagian dari lakon akad dan model pengembangan ekonomi yang berbasis syariah (Sudirman \& Arofah, 2016).

\subsection{Pra Pengembangan Aset: Identifikasi dan Organizing}

Lembaga Wakaf Sabilillah Malang menjadi penerima penghargaan dari Kementerian Agama sebagai lembaga pengelolaan aset wakaf percontohan nasional. Penyematan ini bukan tanpa alasan, produktifitas pengembangan aset wakaf mampu menyulap masyarakat setempat menjadi berdaya. Manajemen aset wakaf produktif 
berupa sarana ibadah (masjid) mampu bermetemorfosis terpecah pada sektor-sektor ekonomi untuk mensejahterakan masyarakat. Peran Masjid Sabilillah Malang, nyaris seperti posisi Baitul Maal pada masa keemasan Dinasti Abbasiyah, menjadi pusat perekonomian negara dalam mengelola aset. Masjid Sabilillah Malang, bukan hanya sarana ibadah semata, namun segala aktifitas sosial dan ekonomi berada pada satu paket manajemen.

Gerakan pengembangan aset wakaf disana, menyisir semua usaha-usaha kecil untuk dikembangkan dengan model menajamen ekonomi syariah secara profesional. Sehingga pada perkembangannya terus menanjak dan mengundang pada waqif untuk melakukan deposito atau gerakan wakaf uang. Dalam teori investasi dan konsumen, hal demikian wajar adanya, sebab suatu variabel mikro profit dapat mendatangkan investor secara besar-besar (Nurvianda et al., 2019). Keberhasilan mengembangkan usaha/bisnis ini tidak terlepas dari strategi identifikasi dan pengorganisasian aset wakaf yang dimiliki sebagai sumber daya, identifikasi aset wakaf yang dimiliki Laziz Sabilillah Malang adalah :

Pertama, wakaf uang atau tunai. Model pengelolaan wakaf tunai di Sabilillah Malang berbeda dengan model pengelolaan wakaf tunai pada umumnya. Pembayaran wakaf tunai dibayar secara bertahap atau diangsur sampai pada akad nominal yang disepakati. Hal ini berbeda dengan konsep pada umumnya yang membayar wakaf tunai secara konstan (Aziz, 2017). Kedua, wakaf tanah. Aset wakaf berupa tanah ini terpakai untuk pembangunan gedung, tanpa ada bagian tanah yang dikosongkan. Diatasnya dibangun TK, SD, SMP, SMA dan pondok pesantren. Ketiga, aset wakaf berupa dana pembangunan diberi nama dengan istilah dana maslahah. Merupakan himpunan dana sukarela dari para jamaah selepas pengajian di masjid. Aset ini digunakan untuk perbaikan dan pengembagan aset produktif lainnya.

Selain masjid sebagai pusat pengembangan aset wakaf, Lembaga Wakaf Sabilillah Malang juga mengembangkan aset berupa pendidikan dari jenjang TK sampai SLTP dan pesantren, bahkan memiliki Lembaga Pendidikan Islam (LPI); Lembaga Layanan Kesehatan yang bekerjasama dengan Rumah Sakit Islam; dan koperasi yang membawahi unit pertokoan, BMT dan Pujasera. Hasil manajemen aset wakaf, mampu mengembangkan usaha, memberikan intensif, kredit usaha mikro dan modal pada puluhan peguyuban. Prestasi ini tidak lepas dari pendekatan model manajemen aset yang digalakkan oleh lembaga wakaf Sabilillah Malang dengan menggunakan pendekatan kerifan lokal berbasis sosial-ekonomi. Kearifan lokal merupakan pendekatan bisnis yang efektif dan efisien dengan dampak positif dua hal; kekayaan daerah yang dikembangkan dan menimbulkan sosialisme ekonomi yang merata (Dewi et al., 2019). Di bawah ini merupakan bagan strategi pengembangan aset wakaf di Laziz Sabilillah Malang. 


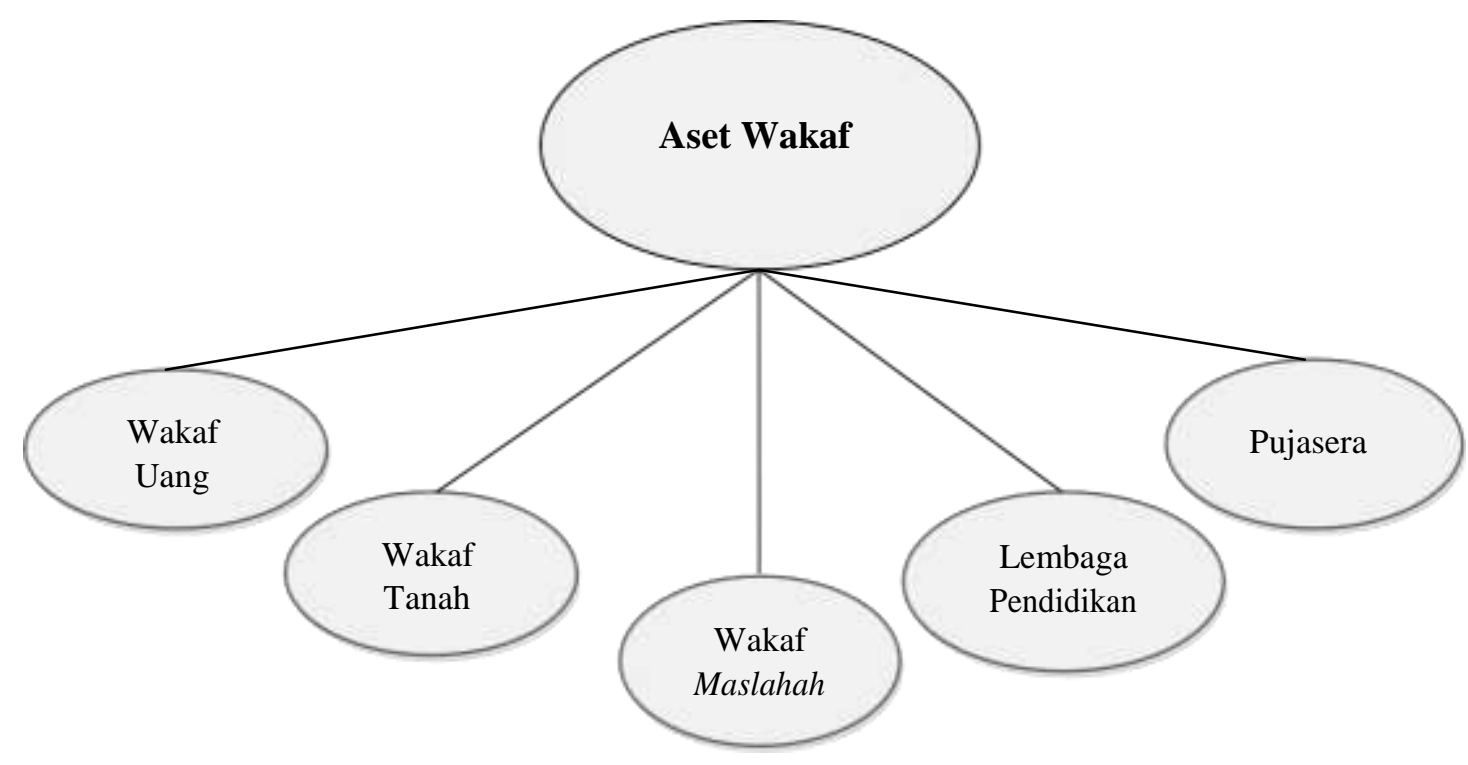

Bagan 1: Identifikasi Aset Wakaf di Laziz Sabilillah Malang

Dari bagai diatas, menggambarkan bahwa Laziz Sabilillah Malang memiliki aset wakaf yang plural. Mulai dari tipe masyarakatnya yang ganderung bersedekah sampai pada kepedulihan mereka mengelola bisnis swadaya. Model kelonggaran dalam menghimpun wakaf uang dengan sistem kredit tanpa bunga, memaksimalkan tanah sebagai lembaga pendidikan dan bisnis, keganderungan untuk bersedekah, lembaga pendidikan yang berjenjang dan bisnis Pujasera dengan basis syariah, menjadikan segala aset berlari kencang untuk mencapai tujuan pemberdayaan umat.

Disadari bersama, sebagai tempat ibadah yang juga bermuatan sosial dan ekonomi umat, perlu melakukan manajemen baik kelembagaan maupun aset yang ada. Sesuai dengan unsur manajemen, langkah pertama yang dilakukan adalah membuat perencanaan selama 2-5 tahun ke depan (Suripto, 2016). Model perencanaan yang dilakukan oleh timwork Sabilillah Malang adalah dengan membuat peta aset lokal atau identifikasi aset lokal. Pemetaan aset merupakan langkah identifikasi pra-implementasi untuk mengukur peluang dan resiko. Identifikasi atau pemetaan aset yang diterapkan termodel pada tiga bagian, dijelaskan dibawah ini.

Pertama, aset manusia. Karakter dan attitude manusia berpengaruh besar terhadap etos kerja, profesionolitas dan tanggungjawab (Samsuni, 2017). Suatu desa atau daerah, dapat mengembangkan potensi lokalnya jika sumber daya manusia yang dimiliki mampu bekerjasama dan bermusyawarah dengan rukun. Ini yang dimaksud dengan keterpaduan antara karakter dengan pengetahuan. Pola kehidupan masyarakat di Sabilillah Malang demikian pula adanya. Tipe masyarakat yang berbaur antara pribumi dengan perkotaan, menjadikan pola sosial mereka bersifat elastis (mixculture lag). Sehingga menciptakan karakter manusia yang memiliki daya kerja tinggi sekaligus rasa solidaritas yang mapan.

Beberapa identifikasi aset manusia yang terhimpun saat membuat perencanaan manajemen aset adalah 1) etos kerja masyarakat Sabilillah Malang sangat tinggi sehingga mereka mudah diajak kerjasama mengembangkan aset wakaf; 2) pola 
kehidupan individu yang ganderung pada kemandirian, dimana setiap keluarga memiliki bisnis mandiri tanpa mengantung pada warisan; 3) ada banyak kerajinan yang ditekuni masyarakat, seperti anyaman bambu, budidaya ikan, dan lain-lain; 4) minimnya konflik individu; 5) antusiasme pada Masjid Sabilillah Malang selain juga karena warisan perjuangan bangsa; 6) sifat atau aura interpreneur dari masingmasing individu.

Kedua, aset alam. Letak geografis Lembaga Wakaf Sabilillah Malang berada tepat di tengah-tengah kota Malang. Wilayah yang dikelilingi oleh tempat usaha bisnis kecil mulai dari pedagang emperan, pasar, konveksi, serta UMKM yang sesak tapi tertata rapi. Selain itu, tempat tinggal masyarakat yang terpisah dari tempat usaha, tetap menampilkan iklim pedesaan yang kental nilai-nilai relegiusitas, kekeluargaan dan gotong royong. Tidak banyak aset alam yang dimiliki, namun letak gegrafis dan mudah dijangkau menjadi takdir istimewa untuk mengambangkan aset. Memang, sebagian besar masyarakatnya rela mewakafkan lahan untuk kepentingan umat.

Beberapa aset alam yang dimiliki lembaga wakaf Sabilillah Malang adalah 1) letak strategis lokasi lembaga wakaf Sabilillah Malang yang berada di pusat ekonomi dan sosial; 2) aset tanah wakaf yang strategis untuk dikembangkan; 3) menjadi lalulalang aktifitas perekonomian masyarakat Malang; 4) pengembangan budidaya ikan, persawahan, wisata alam yang sangat potensial. Seluruh aset alam ini, menjadi potensi yang berhasil dikembangkan dan sebagian besar pekerja bisnis ini menjadi mitra yang dedikatif.

Ketiga, aset sosial. Tingkat solidaritas dan kekeluargaan adalah modal sosial utama untuk mengembangkan aset wakaf (Fathy, 2019). Tipe masyarakat yang memiliki tingkat kekeluargaan dan kepeduliaan baik pada hubungan individu, sosial maupun kelembagaan (Hamid, 2016). Tipe hubungan masyarakat seperti ini, persis yang tergambar di Sabilillah Malang. Sekalipun aktifitas padat untuk kegiatan ekonomi, namun rasa sosial dan religiutas menjadi yang utama. Sehingga, jika ada kepentingan sosial dan pemberdayaan umat, masyarakat paling suka dan semangat.

Aset sosial yang terindefikasi di Lembaga Wakaf Sabilillah Malang adalah 1) tipe sosial yang mekanik, pekerja keras dan peduli sesama; 2) tingkat relegiusitas yang terjalin kolektif dan rasa peduli terhadap tempat ibadah atau Masjid Sabilillah Malang; 3) tingkat etos kerja yang dipadukan dengan rasa sosial tinggi. Aset sosial inilah yang dijadikan patokan dalam mengambangkan aset wakaf. Apalagi, aset wakaf merupakan kegiatan filantropi Islam, menjadikan masyarakat memiliki rasa memiliki dan menjaga serta mengembangkan.

Identifikasi aset wakaf ini menjadi pola menajamen aset yang dikebangkan oleh Lembaga Wakaf Sabilillah Malang. Semua aset (manusia, alam dan sosial) diintegrasikan dalam setiap program dan pengemabangan aset wakaf. Menjadi pertimbangan dan pedoman saat menjalankan semua kegiatan produktif. Bahkan aset wakaf sampai dengan tiga tahun terakhir, meningkat terus. Inilah yang menjadi strategi pengembangan aset wakaf yang produktif. Identifikas aset wakaf di Laziz Sabilillah Malang dapat dilihat dari bagan dibawah ini. 


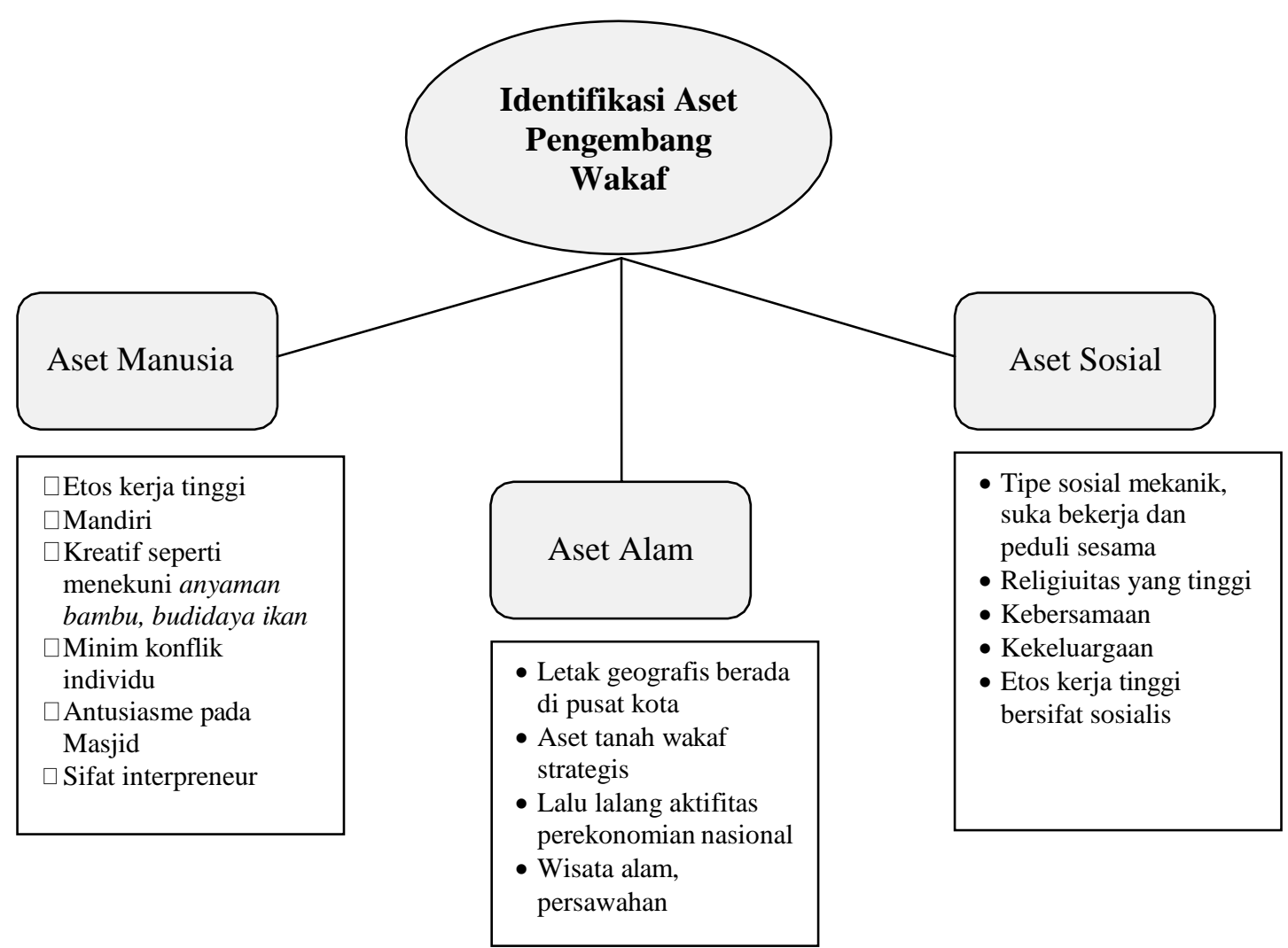

Bagan 2: Pola Pengembang Aset Wakaf di Laziz Sabilillah Malang

Dari bagan diatas, dapat dipahami bahwa selain identifikasi aset wakaf berupa hal bersifat fisik, juga dilakukan identifikasi yang mendukung untuk dikembangkan sebagai pengembang aset wakaf. Segala konsep dan strategi manajemen aset wakaf didasarkan pada pola pengembang yang berhasil diidentifikasi. Seperti halnya di Laziz Sabilillah Malang, ketiga pengembang aset wakaf ini (aset manusia, aset alam dan aset sosial) diintegrasikan untuk saling mendukung dalam rangka mencapai tujuan utama. Ketiga aset ini harus mampu dibaca dan bekerjasama.

\section{Manajemen Aset Sosio-Ekonomi Berbasis Lokal}

Masjid Sabilillah Malang sebagai aset wakaf produktif menjadi cikal bakal terciptanya multifungsi beberapa bidang sektor; ibadah, sosial dan ekonomi. Namun sebenarnya, pengembangan multisektor ini tidak lepas dari orientasi atau pendekatan yang digunakan oleh pengurus lembaga dalam melakukan manajemen. Pola pendekatan yang digunakan adalah kearifan lokal. Suatu pendekatan yang memaksimalkan potensi-potensi lokal sebagai sasaran, termasuk potensi lokal pendukung lainnya seperti sosial dan etos kerja (Jundiani, 2018). Berikut dijelaskan pola manajemen aset tersebut, yaitu:

Pertama, orientasi nasabah/anggota. Animo dan semangat besar untuk melakukan suatu pekerjaan, merupakan salah satu potensi lokal yang bersifat sumber daya (Djakfar, 2017). Sumber daya dibagi dua bagian; sumber daya manusia dan sumber daya alam. Sebagai sumber daya, Lembaga Wakaf Sabilillah Malang benar- 
benar memoles masyarakat dengan pelayanan yang mudah. Hal ini tampak dari model perekrutan anggota wakif pada akad wakaf tunai yang dilaksanakan disana.

Dalam melakukan penghimpunan wakaf tunai, lembaga wakaf Sabilillah Malang menggunakan model pembayaran angsuran. Implikasi angsuran/kredit yang dimaksud tidak sama dengan model kredit pada bank-bank konvensional. Bagi wakif mendatangi lembaga dengan mendaftarkan diri sebagai wakif, kemudian memantabkan akad apakah wakaf tunai dibayarkan setiap bulan, apakah secara kontan, apakah diangsur dengan jumlah maksimal ditentukan diawal dan sebagainya. Dalam melakukan perekrutan dan transaksi wakaf tunai, lembaga wakaf Sabilillah Malang mengikuti pola yang diinginkan oleh wakif, yang terpenting seluruh syarat dan ketentuan wakaf tunai telah sesuai dengan aturan syariah. Secara tidak langsung, model seperti ini hampir sama dengan model fokus produsen atau wakif berdasar pada teori total quality management, menurut Sirajuddin, fokus pada wakif atau pelanggan (S. N. Sirajuddin et al., 2018).

Kemudian, wakaf tunai yang terhimpun dikelola berbasis syariah, termasuk menerapkan akad mudharabah, murabahah dan musyarakah. Dana yang terhimpun misal tahun 2018, dana wakaf tunai sejumlah 1.207.829.000- dana tersebut disalurkan ke berbagai usaha-usaha rakyat baik sebagai investasi, bagi hasil dengan akad musyarakah maupun akad mudharabah. Hasil atau laba dari usaha tersebut didistribusikan kepada fakir miskin, janda, anak yatim, pembangunan, pemerilaharaan, intensif, beasiswa, bedah rumah dan kegiatan lain yang sifatnya mengentaskan kemiskinan.

Kedua, maksimalisasi aset lokal melalui peran UMKM. Disinilah letak kecerdasan lembaga wakaf Sabilillah Malang dalam mengelola aset. Selain dengan mamanfaatkan aset lokal, juga pandai melihat situasi yang ada. Aset lokal dengan kondisi yang ada, dipadukan sebagai wadah manajemen aset. Dari pemetaan potensi lokal dan aset geografis, pelaksanaan manajemen digalakan dengan efektif. Pada tahap ini proses manajemen telah sampai pada organizing dan actuating.

Pada aspek pengembangan potensi lokal, dibangun beberapa upaya bisnis menggunakan wakaf tunai dan laba investasi. Diataranya adalah Koperasi Masjid Sabilillah (Kopmas) dan Lembaga Dana Sosial (Ledsos). Koperasi dan lembaga ini diperuntukan sebagai bait al-Maal berfungsi untuk membantuk perekonomian masyarakat yang sedang lesu atau berkembang. Sedangkan Ledsos, berperan memberikan bantuan modal pada pelaku usaha pemula maupun ingin membuka usaha. Selain itu, koperasi juga membuka usaha pribadi seperti pembangunan Pujasera dan Minimarket.

Dengan mendirikan usaha komersiil miliki lembaga, seperti Pujasera dan minimarket, lembaga Sabilillah Malang juga membangun gedung auditorium/gedung serbaguna. Dikelola oleh masyarakat sebagai bentuk lapangan kerja sekaligus dijadikan tempat acara, even, perkawinan dan sebagainya yang manfaat dari penyewaan tersebut untuk lembaga wakaf. Pada sisi lain, beberapa UMKM disupport dengan modal atau dana pengembangan, ada yang menggunakan akad mudharabah ataupun musyarakah. Berikut digambarkan mengenai pola manajemen aset wakaf berbasis kearifan lokal dengan pendekatan sosio-ekonomi di Laziz Sabilillah Malang. 


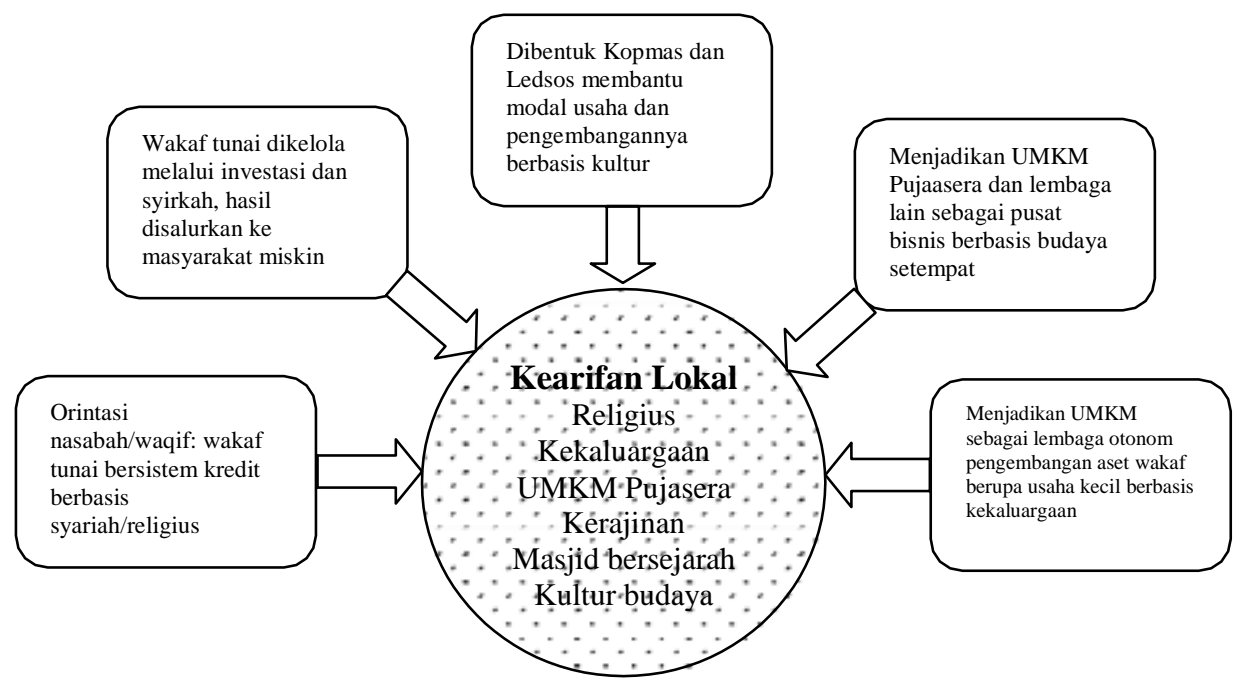

Bagan 3 : Manajemen Aset Wakaf Berbasis Kearifan Lokal dengan Pendekatan Sosio-Ekonomi di Laziz Sabilillah Malang

Bagan ini menggambarkan bahwa pola manajemen aset wakaf di Sabilillah Malang terlabih dahulu mengidentifikasi bentuk kearifan lokal yang dijalankan oleh masyarakat. Kearifan lokal yang mampu menjaga stabilitas sosial masyarakat dengan berbagai perubahan yang menimpa. Selanjutnya, strategi manajemen pengembangan aset wakaf diintegralkan ke dalam bentuk kearifan lokal dengan cara pandang pemberdayaan masyarakat dari aspek ekonomi. Sehingga aset wakaf benar-benar bisa terkelola dengan tepat dan efektif. Dengan demikian, segala upaya manajemen aset wakaf memiliki arah lurus tepat pada sistem masyarakat yang berjalan paralel bersamaan dengan kearifan lokal.

\section{Kesimpulan}

Dari kajian dan bahasan di atas, dapat diambil beberapa simpulan penting, yaitu: pertama, dalam melakukan proses manajemen aset yang pertama dilakukan adalah idenifikasi aset baik berupa aset manusia, alam dan aset sosial. Ketiga aset ini disebut dengan aset sumber daya. Identifikasi harus akurat, sebab disinilah letak perencanaan disusun. Dari identifikasi aset ini pula, resiko dan keuntungan yang didapatkan nanti akan kelihatan seperti yang telah dipraktekan oleh lembaga wakaf Sabilillah Malang.

Kedua, mengembangkan aset melalui maksimalisasi potensi lokal. Beberapa potensi lokal yang teridentifikasi, dikembangkan melalui penyediaan fasilitas. Potensi aset sosial dijadikan pengarah dan pelaksana untuk mengembangkan aset wakaf. Dibangun beberapa usaha bisnis melalui aset wakaf seperti koperasi, minimarket, pujasera yang semua unsur pengebangan ini dibawah kordinasi langsung pusat perekonomian dan pemberdayaan.

Ketiga, mengembangkan aset wakaf melalui maksimalisasi sumber potensi lokal dengan cara menggandeng usaha-usaha bisnis kecil sebagai mitra usaha, mendirikan usaha-usaha dengan cara memberikan modal dan mengembangkan usaha dengan cara kredit. Semua kerjasaam ini dibungkus dengan menggunakan akad mudharabah, murabahah dan musyarakah. Sehingga antara ibadah, sosial dan 
ekonomi berjalan seiraman melalui manajemen aset yang dilakukan oleh Lembaga Wakaf Sabilillah Malang. 


\section{DAFTAR PUSTAKA}

Akhmad Sirojudin Munir. (2015). Optimalisasi Pemberdayaan Wakaf Secara Produktif. Jurna Ummul Quro, VI(2), 94-109.

Alhifni, A., Huda, N., Anshori, M., \& Trihantana, R. (2017). WAQF an instrument of community empowerment in Islamic Boarding School Daarut Tauhiid in Indonesia. Journal of Islamic Economics, Banking and Finance, 23(3), 239-256. Amania, N. (2018). Pengelolaan Aset Wakaf Yayasan Badan Wakaf (YBW) Al21.

Ikhsan Kudus Untuk Anak Yatim. ZISWAF: Jurnal Zakat Dan Wakaf, 5(1),1-

Asy`ari, M. (2017). Problematika Tata Kelola Wakaf Di Lingkungan Muhammadiyah Aceh. Jurnal Ilmiah Islam Futura, 16(1), 1-20.

Asytuti, R. (2017). Optimalisasi Wakaf Produktif. Jurnal Studi Ekonomi At Taradhi, $3(1), 45-54$.

Aziz, M. W. (2017). Wakaf Tunai Dalam Perspektif Hukum Islam. International Journal Ihya' 'Ulum Al-Din, 19(1), 1-24.

Azizah, S. N. (2018). Model pengembangan ekonomi pesantren berbasis kearifan lokal: studi kasus Ponpes Sidogiri Pendahuluan. 68-76.

Daniah. (2016). Kearifan Lokal (Local Wisdom) Sebagai Basis Pendidikan Karakter. PIONIR: Jurnal Pendidikan, 9(2), 47-61.

Dewi, I., Binar, K., \& Surabaya, U. N. (2019). Elsii Learning Model Based Local Wisdom To Improve Students, International Journal of Education and Research, 5(1), 107-117.

Djakfar, M. (2017). Guarding sharia economy in indonesia optimization of contemporary ulama authority and local wisdom. El harakah (terakreditasi), 19(2), 209-226.

Fahmi, A., Fahmi, A., \& Sugiarto, E. (2016). Sistem Informasi Geografis Untuk Pengelolaan Dan Monitoring Persebaran Aset Wakaf.I Jurnal Techno, 15(4), 327-334.

Fathy, R. (2019). Modal Sosial: Konsep, Inklusivitas dan Pemberdayaan Masyarakat. Jurnal Pemikiran Sosiologi, 6(1), 1-17.

Hamid, S. A. (2016). Pengaruh Media Massa Terhadap Perubahan Sosial Masyarakat. Journal of Social Sciences and Humanities, (Special Issue I), 214226.

Jundiani. (2018). Local Wisdom in the Environmental Protection and Management. IOP Conference Series: Earth and Environmental Science, 175(1), 1-7. .

Lexy J. Moleong, D. M. A. (2019). Metodologi Penelitian Kualitatif ( $1^{\text {st }}$ Ed,). PT. Remaja Rosda Karya.

Margolang, N. (2018). Pemberdayaan Masyarakat. Dedikasi: Journal of Community Engagment, https://doi.org/10.31227/osf.io/weu8z

Moleong, L. J. (2017). Metodologi Penelitian Kualitatif (Edisi Revisi). In PT. Remaja Rosda Karya.

Nilna, F. (2015). Rekonstruksi Pengelolaan Wakaf: Belajar Pengelolaan Wakaf Dari Bangladesh dan Malaysia. Universum.5(8), 1-8.

Nurvianda, G., . Y., \& Ghasarma, R. (2019). Pengaruh Keputusan Investasi, Keputusan Pendanaan dan Kebijakan Dividen Terhadap Nilai Perusahaan. 
Jurnal manajemen dan bisnis sriwijaya, 16(3., (73-80).

Pesurnay, A. J. (2018). Local Wisdom in a New Paradigm: Applying System Theory to the Study of Local Culture in Indonesia. IOP Conference Series: Earth and Environmental Science, 175(2), 25-26.

Rahmawati, R. (2016). DINAMIKA AKAD DALAM TRANSAKSI EKONOMI SYARIAH. Al-Iqtishad: Journal of Islamic Economics, 175(2), 25-26.

Ramdani, E. (2018). Model Pembelajaran Kontekstual Berbasis Kearifan Lokal sebagai Penguatan Pendidikan Karakter, Jupiis: Jurnal Pendidikan Ilmu-Ilmu Sosial, 10(1), 10-24

Rozalinda. (2015). Manajemen Wakaf Produktif. Raja Gravindo.

Samsuni, S. (2017). Manajemen sumber daya manusia. Al-Falah: Jurnal Ilmiah Keislaman Dan Kemasyarakatan, 10(2), 1-21.

Selasih, N. N., \& Sudarsana, I. K. (2018). Education Based on Ethnopedagogy in Maintaining and Conserving the Local Wisdom: A Literature Study. Jurnal Ilmiah Peuradeun, 6(2), 219-231.

Sirajuddin, S. N., Sudirman, I., Bahar, L. D., \& Al-Tawaha, A. R. (2018). Social economic factors that affect cattle farmer's willingness to pay for artificial insemination programs. Bulgarian Journal of Agricultural Science, 24(4), 574580.

Sirajuddin, S., \& Yolleng, A. (2018). Pemberdayaan Tanah Wakaf Sebagai Potensi Ekonomi Umat Di Masjid Al-Markaz Al-Islami Makassar. LAA MAISYIR: Jurnal Ekonomi Islam, 5(1), 21-35.

Sudirman, S., \& Arofah, N. L. (2016). Manajemen Wakaf Uang di Masjid at-Taqwa Kota Batu dan Masjid Sabilillah Kota Malang dalam Perspektif UndangUndang Nomor 41 Tahun 2004 tentang Wakaf. Journal de Jure, 8(1), 37-43..

Sugiyono. (2016). Memahami Penelitian Kualitatif. Bandung: Alfabeta.

Sugiyono. (2018). Metode Penelitian Kuantitatif,Kualitatif dan R\&D, (26st ed.)

Suhendi, H. H. (2018). Optimalisasi Aset Wakaf Sebagai Sumber Dana Pesantren Melalui Pelembagaan Wakaf (Studi Kasus Pelembagaan Wakaf Pesantren Baitul Hidayah). Tahkim (Jurnal Peradaban Dan Hukum Islam), 1(1), 17-34.

Suripto, T. (2016). Manajemen Sdm Dalam Prespektif Ekonomi Islam: Tinjauan Manajemen Sdm Dalam Industri Bisnis, JESI (Jurnal Ekonomi Syariah Indonesia), 2(2), 239-250

Usman, N. (2013). Pengelolaan Wakaf Produktif Dalam Bentuk Spbu Studi Kasus Spbu Masjid Agung Semarang. Muqtasid: Jurnal Ekonomi Dan Perbankan Syariah, 4(1), 145-163

Usman, N. (2016). Pengelolaan Wakaf Produktif Untuk Kesehatan (Studi Kasus Bandha Wakaf Masjid Agung Semarang). Muaddib: Studi Kependidikan Dan Keislaman, 4(2), 98-112.

Via Olva Novita. (2020). Wealth Management As A Strategy The Management Of An Asset Like A Plot In The Islamic Education Institutions And Has Been Addressed Wealth Management Sebagai Strategi Pengelolaan Aset Lembaga Pendidikan Islam. Islamic Management: Jurnal Manajemen Pendidikan Islam, 3(2), 167-180. 